\title{
PERAN KEPUASAN PELANGGAN DALAM MEMEDIASI PERSEPSI NILAI DAN PENGALAMAN TERHADAP NIAT MEMBELI KEMBALI (Studi kasus pada Toyota Avanza di Kota Denpasar)
}

\author{
Ketut Adi Ananta Shantika ${ }^{1}$ \\ Putu Yudi Setiawan ${ }^{2}$
}

\author{
${ }^{1,2}$ Fakultas Ekonomi dan Bisnis Universitas Udayana, Bali, Indonesia \\ 1e-mail: ketut_ananta@yahoo.com
}

\begin{abstract}
ABSTRAK
Bagi perusahaan perlu memperhatikan faktor-faktor yang dapat mempengaruhi terciptanya niat membeli kembali untuk meningkatkan pendapatan bagi perusahaan. Penelitian ini bertujuan untuk mengetahui pengaruh persepsi nilai, pengalaman, dan kepuasan pelanggan sebagai penyebab terciptanya niat membeli kembali. Penelitian ini dilakukan pada Toyota Avanza di Kota Denpasar. Jumlah sampel digunakan sebanyak 124 responden, dengan metode non-probability sampling, khususnya purposive sampling. Pengumpulan data dilakukdengan menyebarkan kuisioner secara online. Teknik analisis data yang digunakan adalah PLS serta uji sobel. Berdasarkan hasil analisis ditemukan bahwa persepsi nilai, pengalaman, dan kepuasan pelanggan secara langsung berpengaruh positif dan signifikan terhadap niat membeli kembali. Hal ini mengindikasikan, semakin baik nilai yang dirasakan oleh pelanggan, semakin baik pengalaman yang dialami oleh pelanggan dan semakin puas pelanggan akan suatu produk dapat meningkatkan niat pelanggan tersebut untuk kembali melakukan pembelian pada produk tersebut di masa yang akan datang. Selain itu, persepsi nilai dan pengalaman secara tidak langsung dapat mempengaruhi niat membeli kembali melalui kepuasan pelanggan sebagai variabel mediasi.
\end{abstract}

Kata kunci : persepsi nilai, pengalaman, kepuasan pelanggan, niat membeli kembali

\begin{abstract}
A company should consider some factors affects repurchase intention, to increase a company's income. A goal of this research is to know the effect of perceived value, experience and customer satisfaction as a causal factor to the repurchase intention. This research applied in Toyota Avanza in Denpasar City, Bali - Indonesia. The sample used is 124 respondents, with a non-probability method, especially purposive sampling. Data collection did by giving questionnaire through online. Analytic techniques used are Partial Least Square and Sobel Test. Based on this analysis, found that perceived value, experience, and customer satisfaction significantly and positively affects repurchase intention directly, its mean better value got by the customer, better experience, and more satisfied customer would increase customer intention to repurchase, beside that perceived value and experience indirectly affects repurchase intention through customer satisfaction as a mediator. This result shows, better-perceived value has by the customer, better customers' experiences, better customer satisfaction could increase the intention to repurchase in the future for the same product.
\end{abstract}

Key Words : perceived value, experience, customer satisfaction, repurchase intention 


\section{PENDAHULUAN}

Di era moderen saat ini, transportasi telah menjadi salah satu bagian dari kehidupan sehari-hari. Orang-orang mencari berbagai macam alternatif yang bisa digunakan untuk melakukan travelling. Saat ini mobil menjadi salah satu hal yang selalu dijumpai setiap hari, terlebih lagi pada kota-kota besar di Indonesia ketersediaan transportasi publik belum cukup memadai, begitu pula di Kota Denpasar, meskipun pemerintah sudah memfasilitasi adanya transportasi publik, tetapi belum dapat memenuhi kebutuhan masyarakat Kota Denpasar sehingga banyak masyarakat memilih untuk menggunakan mobil pribadi untuk berpergian.

Penggunaan mobil meningkat selama tujuh tahun belakangan, peningkatan yang paling signifikan dari penggunaan mobil terlihat pada tahun 2012, di mana penjualan mobil meningkat sebesar 25 persen dari 894.164 unit ke 1.116 .230 unit (Harsono, 2016). Pada tahun 2014, di Indonesia industri otomotif mengalami penurunan jumlah penjualan, dikarenakan adanya kenaikan harga Bahan Bakar Motor (BBM) subsidi. Meskipun demikian, di awal tahun 2016, penjualan mobil Indonesia meningkat sebesar 15,86 persen.

Pemimpin di industri otomotif Indonesia adalah Toyota Avanza. Mobil dengan kapasitas penumpang lebih menjadi mobil yang paling digemari di Indonesia (Harsono, 2016). Toyota Avanza memiliki spesifikasi 7 tempat duduk penumpang dan pengemudi, dengan kapasitas mesin $1.329 \mathrm{cc}, 91$ Horse Power, dilengkapi dengan kenyamanan power steering serta keamanan kantong udara bagi pengemudi, dilengkapi dengan sistem anti lock braking, yaitu sistem keamanan mobil yang dirasakan ketika mobil direm secara keras dan tiba-tiba 
tidak akan membuat ban mobil terkunci sehingga mobil meluncur dan tak terkendali, menjadikan Toyota Avanza muncul sebagai salah satu mobil yang paling digemari sejak hadir di dunia otomotif Indonesia pada tahun 2003 (Oto.com, 2018).

Berbeda dengan data yang berhasil diperoleh, yang menyebutkan Toyota Avanza menjadi market leader di industri otomotif Indonesia, Gabungan Industri Kendaraan Bermotor Indonesia (GAIKINDO) mempublikasikan terdapat penurunan penjualan Toyota Avanza di Indonesia pada Januari 2017 hingga April 2018, sesuai dengan data yang disajikan dalam Tabel 1 berikut,

Tabel 1.

Data Penjualan Toyota Avanza di Indonesia

\begin{tabular}{cc}
\hline Bulan (Tahun) & Total Penjualan (Dalam ribuan unit) \\
\hline Januari - April (2017) & 47,6 \\
Mei - Agustus (2017) & 34,3 \\
September - Desember (2017) & 34,4 \\
Januari - April (2018) & 28,3 \\
\hline
\end{tabular}
Sumber: Gaikindo, 2018

Berdasarkan data yang disajikan pada Tabel 1 terlihat bahwa terjadi fluktuasi penjualan Toyota Avanza dari Januari 2017 hingga April 2018, jika dilakukan perbandingan year-on-year dari data tersebut, terlihat perbedaan yang signifikan pada data penjualan Januari-April pada Tahun 2017 dengan data penjualan pada Januari-April pada Tahun 2018, yang dapat jika dipersentasekan diperoleh penurunan sebesar 40,54 persen. Penurunan penjualan Toyota Avanza di Bali juga dibenarkan oleh Muhammad Fauzi selaku Regional Agung Toyota wilayah Timur, dikarenakan adanya pemain baru dalam industri terkait (Kusniarti, 2018). 
Menurunnya tingkat penjualan Toyota yang sanagat signifikan ini merupakan masalah besar yang dihadapi oleh PT. Toyota-Astra Motor. Hal ini tentu menjadi tanggungjawab dari manajer perusahaan, bergantung pada kiat-kiat dan strategi pemasaran yang dilakukan karena dengan penerapan strategi pemasaran yang tepat, perusahaan dapat menciptakan, memelihara, dan mengembangkan permintaan pelanggan secara meyakinkan dan berkesinambungan. Apabila nilai penjualan mengalami peningkatan yang lambat atau tidak signifikan, manajer hendaknya melakukan analisa faktor apa saja yang berdampak pada lambatnya peningkatan penjualan atau bahkan penurunan.

Menurunnya penjualan Toyota Avanza tersebut diperkirakan karena menurunnya niat membeli kembali pelanggan Toyota Avanza yang disebabkan adanya ketidakpuasan pelanggan akan Toyota Avanza yang merupakan dampak dari perubahan persepsi nilai pelanggan akan Toyota Avanza dipengaruhi pula oleh pengalaman yang dialami pelanggan selama menggunakan Toyota Avanza. Fenomena ini diperkirakan pula terjadi karena adanya pesaing baru di kelas city car Indonesia, yaitu Mitsubishi Xpander, dengan harga yang sedikit lebih mahal fitur yang ditawarkan oleh Mitubishi Xpander lebih lengkap jika dibandingkan. Hal ini didukung oleh penelitian sebelumnya yang disebutkan bahwa dalam meningkatkan niat untuk membeli kembali suatu produk, perusahaan harus memperhatikan beberapa variabel yaitu atribut produk, persepsi nilai, pengalaman pelanggan, dan kepuasan pelanggan (Idris, 2017).

Penelitian ini bertujuan untuk menjelaskan pengaruh langsung persepsi nilai, pengalaman, dan kepuasan pelanggan terhadap niat membeli kembali, serta 
Ketut Adi Ananta Shantika, Peran Kepuasan Pelanggan..

untuk menjelaskan peran kepuasan pelanggan dalam memediasi persepsi nilai dan pengalaman terhadap niat membeli kembali. Penelitian ini dapat dijadikan refrensi dan mampu memberikan informasi bagi pelaku bisnis otomotif khususnya produsen mobil, serta mengidentifikasi variabel dan indikator persepsi nilai, pengalaman, dan niat membeli kembali.

Wibowo dkk. (2014) menjelaskan bahwa persepsi nilai memiliki dampak yang signifikan terhadap kepuasan yang dirasakan oleh pelanggan. Meningkatnya persepsi nilai akan berpengaruh pada kepuasan pelanggan, pelanggan yang puas menandakan bahwa ekspektasi telah terlewati (Adhy, 2016). Persepsi nilai mempengaruhi kepuasan pelanggan, yang tercipta dari kombinasi akan elemen kualitas layanan (Hume \& Mort, 2010). Berdasarkan temuan tersebut, dirumuskan hipotesis berupa:

$\mathrm{H}_{1}$ : Persepsi nilai berpengaruh positif dan signifikan terhadap kepuasan pelanggan.

Sun et al. (2016) menjelaskan bahwa akumulasi dari informasi produk dan pengalaman dalam berbelanja selama transaksi akan mempengaruhi persepsi kualitas dan kepuasan pelanggan. Selain itu, Idris (2017) mengemukakan bahwa pengalaman pelanggan akan berdampak secara signifikan terhadap kepuasan pelanggan suatu produk atau jasa. Semakin baik pengalaman selama berbelanja akan mempengaruhi peningkatan kepuasan pelanggan (Suandana dkk., 2016). Pengalaman pelanggan dapat mempengaruhi pengaruh kepuasan pelanggan (Pappas et al., 2014). Berdasarkan temuan tersebut, dirumuskan hipotesis berupa: $\mathrm{H}_{2}$ : Pengalaman berpengaruh positif dan signifikan terhadap kepuasan pelanggan. 
Persepsi nilai secara langsung mempengaruhi niat membeli kembali, serta dapat memediasi hubungan antara persepsi harga terhadap niat membeli kembali (Ayuniar dkk., 2017). Persepsi nilai terbukti sebagai predictor yang positif dan signifikan, ketika persepsi nilai meningkat, akan meningkatkan niat pelanggan untuk membeli kembali (Fang et al., 2016). Semakin tinggi persepsi nilai akan secara positif mempengaruhi tingkat niat pelanggan untuk membeli kembali produk yang sama (Younus et al., 2015). Berdasarkan temuan tersebut, dirumuskan hipotesis berupa:

$\mathrm{H}_{3}$ : Persepsi nilai berpengaruh positif dan signifikan terhadap niat membeli kembali.

Niat pelanggan untuk membeli kembali produk yang sama secara positif dan signifikan dipengaruhi oleh atribut produk, persepsi nilai, pengalaman pelanggan, dan kepuasan pelanggan (Idris, 2017). Pengalaman terkait merek memiliki pengaruh yang positif pada loyalitas merek, yang dapat dibuktikan dengan keinginan pelanggan untuk melakukan pembelian ulang (Hussein, 2018). Pengalaman yang baik selama mencari informasi terkait produk dan kemudahan dalam berbelanja akan mempengaruhi niat pelanggan untuk membeli kembali produk yang sama di masa yang akan datang (Suandana dkk., 2016). Berdasarkan temuan tersebut, dirumuskan hipotesis berupa:

$\mathrm{H}_{4}$ : Pengalaman berpengaruh positif dan signifikan terhadap niat membeli kembali.

Menurut Suandana dkk. (2016) niat membeli kembali secara positif dan signifikan dipengaruhi oleh kepuasan pelanggan. Semakin tinggi kepuasan akan 
menciptakan semakin tingginya niat pelanggan untuk melakukan pembelian ulang (Olli \& Nurcaya, 2016). Kepuasan pelanggan dan niat membeli ulang memiliki hubungan yang sangat kompleks (Bindroo et al., 2016). Ditemukan terdapat tiga dimensi yang dapat secara langsung mempengaruhi niat membeli kembali, yaitu ekuitas merek, kepuasan pelanggan, dan brand resonance (Chun et al., 2014). Tingkat kepuasan pelanggan akan mempengaruhi tingkat niat konsumen untuk melakukan pembalian ulang (Chamchuntra \& Fongsuwan, 2014). Berdasarkan temuan tersebut, dirumuskan hipotesis berupa:

$\mathrm{H}_{5}$ : Kepuasan pelanggan berpengaruh positif dan signifikan terhadap niat membeli kembali.

Kepuasan pelanggan dapat dikatakan menjadi variabel mediasi antara persepsi nilai dan niat membeli kembali (Idris, 2017). Persepsi nilai akan mempengaruhi kepuasan pelanggan, yang juga mempengaruhi niat membeli kembali melalui kepuasan pelanggan (Shih \& Chia, 2016). Niat membeli kembali akan produk hijau secara positif dipengaruhi oleh persepsi nilai melalui kepuasan pelanggan dan green trust (Lam et al., 2016). Chou \& Hsu (2016) juga mengungkapkan bahwa persepsi nilai pelanggan akan mempengaruhi kepuasan pelanggan, yang mana akan berdampak pula pada niat membeli kembali. Persepsi nilai secara langsung mempengaruhi kepuasan pelanggan, dengan kepuasan pelanggan mempengaruhi loyalitas merek, sehingga loyalitas merek yang ditandai dengan munculnya niat pelanggan untuk membeli kembali produk yang sama menjadi meningkat (Kassim et al., 2014). Berdasarkan temuan tersebut, dirumuskan hipotesis berupa: 
$\mathrm{H}_{6}$ : Kepuasan pelanggan secara signifikan memediasi persepsi nilai terhadap niat membeli kembali.

Pengalaman pelanggan secara positif mempengaruhi niat membeli kembali melaui kepuasan pelanggan melalui kepuasan pelanggan sebagai variabel intervening (Idris, 2017). Kepuasan pelanggan sangat signifikan dalam memediasi pengalaman online terhadap niat membeli kembali (Suandana dkk., 2016). Pengalaman pelanggan memiliki pengaruh yang positif dan signifikan pada kepuasan pelanggan, dengan kepuasan pelanggan memiliki pengaruh yang positif dan signifikan terhadap niat membeli kembali, sehingga dapat dikatakan kepuasan pelanggan sebagai mediator antara pengalaman dan niat membeli kembali (Azhari dkk., 2015). Loyalitas pelanggan dapat secara signifikan dipengaruhi oleh informasi kualitas produk, kualitas produk dan kualitas sistem yang dirasakan oleh pelanggan, serta kepuasan pelanggan, ini bermaksud semakin baik kualitas yang dialami oleh pelanggan, dngan kepuasan yang tinggi akan meningkatkan loyalitas pelanggan, dana akan memiliki niat untuk membeli kembali produk tersebut di kemudian hari (Chen et al., 2015). Berdasarkan temuan tersebut, dirumuskan hipotesis berupa:

$\mathrm{H}_{7}$ : Kepuasan pelanggan secara signifikan memediasi pengalaman terhadap niat membeli kembali.

Berdasarkan ketujuh hipotesis di atas, kerangka konseptual untuk penelitian ini adalah: 


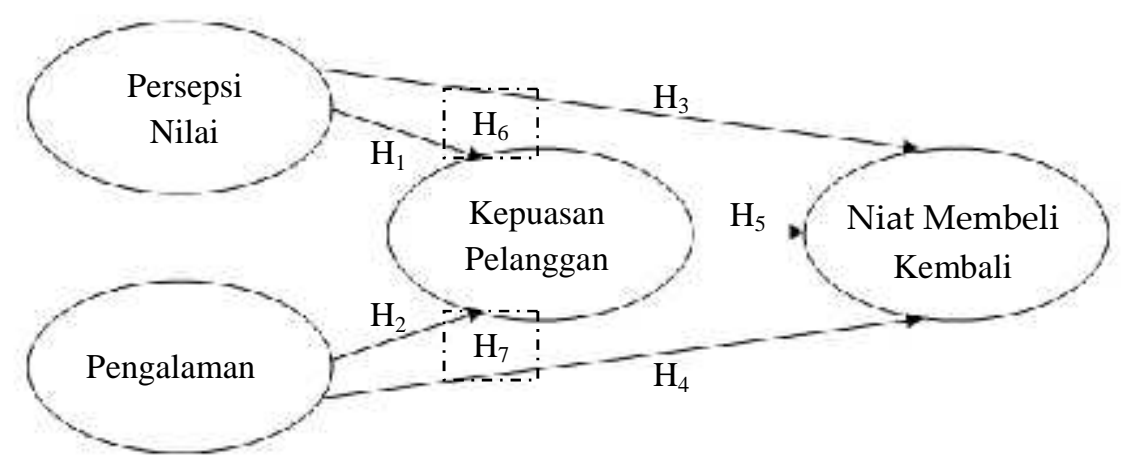

\section{Gambar 1. Kerangka Konseptual}

Sumber:Idris, 2017

\section{METODE PENELITIAN}

Jenis penelitian ini merupakan penelitian asosiatif kausal yang bertujuan untuk mengetahui pengaruh variabel independent terhadap variabel dependent menggunakan teknik analisis kuantitatif. Penelitian ini bertujuan untuk mengetahui pengaruh variabel persepsi nilai dan kepuasan pelanggan terhadap niat membeli kembali, serta mengetahui peran variabel kepuasan pelanggan dalam memediasi persepsi nilai dan pengalaman terhadap niat membeli kembali.

Ruang lingkup penelitian ini adalah bidang manajemen pemasaran, khususnya mengenai faktor yang dapat mempengaruhi munculnya perilaku niat membeli kembali. Penelitian ini dilakukan di Kota Denpasar. Peneliti memilih Kota Denpasar menjadi lokasi penelitian karena Kota Denpasar sebagai kota pusat pemerintahan di Provinsi Bali, menjadi salah satu kota yang memiliki mobilisasi tertinggi di Bali.

Obyek penelitian dalam penelitin ini adalah niat membeli kembali Toyota Avanza yang ditinjau berdasarkan pengaruh persepsi nilai yang dimiliki oleh pelanggan, pengalaman pelanggan, serta kepuasan yang dirasakan oleh pelanggan. 
Variabel penelitian yang digunakan dalam penelitian ini dikelompokkan menjadi variabel terikat (eksogen) dan variabel bebas (endogen). Dalam penelitian ini persepsi nilai $\left(\mathrm{X}_{1}\right)$ menjadi variabel bebas pertama dan pengalaman $\left(\mathrm{X}_{2}\right)$ menjadi variabel bebas kedua, dan kepuasan pelanggan $\left(\mathrm{Y}_{1}\right)$ serta niat membeli kembali $\left(\mathrm{Y}_{2}\right)$ sebagai variabel terikat.

Populasi dari penelitian ini adalah seluruh masyarakat Kota Denpasar yang sudah pernah membeli dan menggunakan produk otomotif Toyota Avanza dengan demikian jumlah populasi yang digunakan dalam penelitian adalah infinite atau tidak terhingga, karena luasnya jangkauan penelitian. Pengumpulan data dilakukan dengan metode penyebaran kuisioner dengan format berupa pernyataan. Isi kuisioner difokuskan pada faktor-faktor yang mempengaruhi niat membeli kembali yaitu persepsi nilai, pengalaman, dan kepuasan pelanggan. Hasil dari masing-masing bagian akan menunjukkan pengaruh faktor-faktor tersebut terhadap terciptanya niat untuk membeli kembali Toyota Avanza. Penilaian variabel dalam kuisioner ini menggunakan skala Likert, yaitu dengan menjabarkan variabel menjadi indikator variabel. Responden menanggapi pernyataan dengan menentukan tingkat persetujuan responden terhadap suatu pernyataan. Indikator yang digunakan dalam penelitian ini tersaji dalam Tabel 2.

Teknik analisis yang digunakan dalam Tabel 2 adalah statistik deskriptif dan statistik inferensial. Statistik deskriptif adalah perhitungan perhitungan statistik, baik menggambarkan karakteristik sampel maupun hubungan antarvariabel dalam sampel. Statistik deskriptif hanya meringkas serangkaian pengamatan sampel 
sedangkan statistik inferensial adalah perhitungan statistik yang membantu peneliti untuk mengambil simpulan tentang populasi (Rahyuda, 2016:254).

Tabel 2.

Indikator Variabel Penelitian

\begin{tabular}{cll}
\hline Variabel & & \multicolumn{1}{c}{ Indikator } \\
\hline Persepsi Nilai & $\mathrm{X}_{1.1}$ & Benefit exceeds cost \\
& $\mathrm{X}_{1.2}$ & Quality functional value. \\
& $\mathrm{X}_{1.3}$ & Social perceived value \\
& $\mathrm{X}_{1.4}$ & Luxury value. \\
Pengalaman & $\mathrm{X}_{2.1}$ & Accessibility. \\
& $\mathrm{X}_{2.2}$ & Promise fulfilment. \\
& $\mathrm{X}_{2.3}$ & Perceived Aesthetics \\
Kepuasan & $\mathrm{X}_{2.4}$ & Experience involvement. \\
Pelanggan & $\mathrm{Y}_{1.1}$ & Perceived value after purchase. \\
& $\mathrm{Y}_{1.2}$ & Product's satisfaction \\
Niat Membeli & $\mathrm{Y}_{1.3}$ & Product's feature satisfaction \\
Kembali & $\mathrm{Y}_{2.1}$ & The tendency of buying the same product \\
& $\mathrm{Y}_{2.2}$ & That's product always become the first option \\
& $\mathrm{Y}_{2.3}$ & Consider doing repurchase in the following time.
\end{tabular}

Sumber : Idris, 2017

Bentuk statistik inferensial yang digunakan dalam penelitian ini adalah Partial Least Squares (PLS) dan uji sobel, dimana PLS merupakan salah satu metode analisa yang bisa diterapkan untuk seluruh skala data, tidak memerlukan asumsi yang banyak, ukuran sampelnya tidak diharuskan besar, dapat dipergunakan untuk pembuktian teori, dan juga dapat digunakan untuk mengembangkan hubungan yang belum mempunyai landasan teori yang kuat. Uji Sobel dilakukan untuk menguji signifikansi pengaruh tidak langsung variabel eksogen terhadap variabel tujuan (endogen) melalui variabel mediasi . Perhitungan uji Sobel dilakukan dengan menggunakan aplikasi Ms. Excel 2007. Nilai koefisien z jika lebih besar dari 1,96, maka variabel mediasi dinilai secara signifikan mampu memediasi hubungan pengaruh vaiabel eksogen terhadap variabel endogen. 
Penelitian ini, peniliti melakukan uji Sobel sebanyak 2 kali, yaitu untuk mengetahui signifikansi tidak langsung pengaruh variabel persepsi nilai $\left(\mathrm{X}_{1}\right)$ terhadap variabel niat membeli kembali $\left(\mathrm{Y}_{2}\right)$ melalui variabel kepuasan pelanggan $\left(\mathrm{Y}_{1}\right)$. Serta untuk mengetahui signifikansi tidak langsung pengaruh variabel pengalaman $\left(\mathrm{X}_{2}\right)$ terhadap variabel niat membeli kembali $\left(\mathrm{Y}_{2}\right)$ melalui variabel kepuasan pelanggan $\left(\mathrm{Y}_{1}\right)$.

\section{HASIL PENELITIAN DAN PEMBAHASAN}

Menurut data yang diperoleh responden didominasi oleh laki-laki, dengan persentase sebesar 62 persen, sedangkan responden perempuan sebesar 38 persen. Berdasarkan kriteria usia responden berusia lebih dari 39 tahun mendominasi dengan persentase sebesar 28,2 persen, sedangkan persentase terendah dimiliki oleh responden dengan rentang usia 19-23 tahun dengan persentase 8,9 persen. Berdasarkan kriteria pendidikan terakhir responden, didominasi oleh responden dengan pendidikan akhir tingkat sarjana dengan persentase sebesar 52,4 persen, sedangkan persentase terendah dimiliki oleh responden dengan pendidikan akhir tingkat SMA sebesar 4 persen. Berdasarkan kriteria pekerjaan responden, didominasi oleh responden dengan pekerjaan PNS / ASN dengan persentase sebesar 32,3 persen, sedangkan persentase terendah dimiliki oleh responden dengan pekerjaan pelajar sebesar 4 persen.

Validitas model konstruk terlebih dahulu diuji, sebelum membahas signifikansi pengaruh langsung masing-masing variabel independent terhadap variabel dependent dalam model penelitian. Outer model dinilai dengan cara 
Ketut Adi Ananta Shantika, Peran Kepuasan Pelanggan..

melihat convergent validity (besarnya loading factor untuk masing-masing konstruk). Penelitian ini menggunakan batas minimal loading factor sebesar 0,5.

Tabel 3.

Outer Loadings

\begin{tabular}{ccc}
\hline Variabel & Indikator & Factor Loading \\
\hline \multirow{3}{*}{ Persepsi Nilai } & $\mathrm{X}_{1.1}$ & 0,831 \\
& $\mathrm{X}_{1.2}$ & 0,855 \\
& $\mathrm{X}_{1.3}$ & 0,898 \\
\multirow{3}{*}{ Persepsi Nilai } & $\mathrm{X}_{1.4}$ & 0,826 \\
& $\mathrm{X}_{1.1}$ & 0,831 \\
& $\mathrm{X}_{2.2}$ & 0,914 \\
\multirow{3}{*}{ Kepuasan Pelanggan } & $\mathrm{X}_{2.3}$ & 0,894 \\
\multirow{3}{*}{ Niat Membeli Kembali } & $\mathrm{X}_{2.4}$ & 0,914 \\
& $\mathrm{Y}_{1.1}$ & 0,892 \\
& $\mathrm{Y}_{1.2}$ & 0,901 \\
& $\mathrm{Y}_{1.3}$ & 0,939 \\
& $\mathrm{Y}_{2.1}$ & 0,940 \\
& $\mathrm{Y}_{2.2}$ & 0,889 \\
& $\mathrm{Y}_{2.3}$ & 0,923 \\
\hline
\end{tabular}

Sumber : Data primer diolah, 2018

Hasil pengolahan pada Tabel 2 mengindikasikan bahwa nilai outer model telah memenuhi kriteria convergent validity, semua indikator memiliki factor loading di atas 0,50 sehingga konstruk mempunyai convergent validity yang baik.

Tabel 4.

Cross Loadings

\begin{tabular}{c|c|c|c|c}
\hline & Kepuasan & $\begin{array}{c}\text { Niat Membeli } \\
\text { Kembali }\end{array}$ & Pengalaman & Persepsi Nilai \\
\hline & & & & \\
$\mathrm{X}_{1.1}$ & 0,650 & 0,636 & 0,631 & $\mathbf{0 , 8 3 1}$ \\
$\mathrm{X}_{1.2}$ & 0,705 & 0,678 & 0,729 & $\mathbf{0 , 8 5 5}$ \\
$\mathrm{X}_{1.3}$ & 0,663 & 0,717 & 0,746 & $\mathbf{0 , 8 9 8}$ \\
$\mathrm{X}_{1.4}$ & 0,683 & 0,747 & 0,658 & $\mathbf{0 , 8 2 6}$ \\
$\mathrm{X}_{2.1}$ & 0,636 & 0,660 & $\mathbf{0 , 8 7 2}$ & 0,706 \\
$\mathrm{X}_{2.2}$ & 0,739 & 0,725 & $\mathbf{0 , 9 1 4}$ & 0,741 \\
$\mathrm{X}_{2.3}$ & 0,716 & 0,777 & $\mathbf{0 , 8 9 4}$ & 0,727 \\
$\mathrm{X}_{2.4}$ & 0,680 & 0,725 & $\mathbf{0 , 9 1 4}$ & 0,740 \\
$\mathrm{Y}_{1.1}$ & $\mathbf{0 , 8 9 2}$ & 0,726 & 0,656 & 0,691 \\
$\mathrm{Y}_{1.2}$ & $\mathbf{0 , 9 0 1}$ & 0,707 & 0,718 & 0,738 \\
$\mathrm{Y}_{1.3}$ & $\mathbf{0 , 9 3 9}$ & 0,771 & 0,734 & 0,734 \\
$\mathrm{Y}_{2.1}$ & 0,749 & $\mathbf{0 , 9 4 0}$ & 0,750 & 0,760 \\
$\mathrm{Y}_{2.2}$ & 0,736 & $\mathbf{0 , 8 8 9}$ & 0,732 & 0,743 \\
$\mathrm{Y}_{2.3}$ & 0,736 & $\mathbf{0 , 9 2 3}$ & 0,734 & 0,742 \\
\hline
\end{tabular}

Sumber: Data primer diolah, 2018 
Cross loading dinilai untuk mengetahui discriminant validity dari model pengukuran dengan reflektif indikator. Data pada Tabel 3 dijelaskan bahwa cross loading menunjukkan adanya discriminant validity yang baik. Hal tersebut dapat dilihat dari nilai korelasi indikator terhadap konstruknya (factor loading) lebih tinggi dibandingkan nilai korelasi indikator tersebut dengan konstruk lainnya.

Menguji reliabilitas dengan membandingkan nilai akar dari Average Variant Extracted (AVE) setiap konstruk dengan korelasi antara konstruk dengan konstruk lainnya.

Tabel 5.

AVE

\begin{tabular}{lcc}
\hline & AVE & Akar AVE \\
\hline Kepuasan Pelanggan & 0,829 & 0,911 \\
Niat Membeli Kembali & 0,842 & 0,918 \\
Pengalaman & 0,808 & 0,899 \\
Persepsi Nilai & 0,728 & 0,853 \\
\hline Sumber: Data & &
\end{tabular}

Sumber: Data primer diolah, 2018

Akar AVE pada Tabel 4 akan dibandingkan dengan nilai korelasi antar variabel bebas seperti ditunjukkan pada Tabel 5 berikut,

Tabel 6.

Korelasi antar Variabel Laten

\begin{tabular}{lcccc}
\hline & Kepuasan & $\begin{array}{c}\text { Niat Membeli } \\
\text { Kembali }\end{array}$ & Pengalaman & $\begin{array}{c}\text { Persepsi } \\
\text { Nilai }\end{array}$ \\
\hline Kepuasan & 1,000 & & & \\
Niat Membeli Kembali & 0,807 & 1,000 & & \\
Pengalaman & 0,773 & 0,805 & 1,000 & \\
Persepsi Nilai & 0,792 & 0,816 & 0,811 & 1,000 \\
\hline Sumber:
\end{tabular}

Sumber: Data primer diolah, 2018

Tabel 4 menunjukkan bahwa akar AVE dengan nilai terendah adalah 0,853.

Nilai korelasi antar konstruk pada Tabel 5 terbesar adalah 0,816, dengan demikian semua nilai akar AVE lebih besar daripada nilai korelasi antar konstruk sehingga dapat dikatakan bahwa data sudah reliabel. 
Selanjutnya setelah model yang diestimasi memenuhi kriteria outer model, pengujian model struktural (inner model) dilakukan. Inner model menggambarkan hubungan antar variabel laten berdasarkan pada substantive theory. Dalam menilai model dengan PLS, dimulai dengan melihat R-squares untuk setiap variabel laten dependen. Hasil pengujian inner model dapat melihat hubungan antar konstruk dengan membandingkan nilai signifikansi dan R-squares dari model penelitian (Putra dkk., 2018).

Tabel 7.

Nilai R-squares

\begin{tabular}{cc}
\hline Variabel & R Square \\
\hline Kepuasan & 0,677 \\
Niat Membeli Kembali & 0,761 \\
\hline Sumber: Data primer diolah, 2018
\end{tabular}

Data pada Tabel 6 menunjukkan bahwa nilai R-squares variabel kepuasan pelanggan pada tabel sebesar 0,677 ini berarti bahwa 67,7 persen variabilitas konstruk kepuasan pelanggan dijelaskan oleh variabel pengalaman dan persepsi nilai pelanggan, sedangkan 32,3 persen variabel kepuasan pelanggan dipengaruhi oleh variabel selain di dalam model. Demikian pula nilai R-squares variabel niat membeli kembali sebesar 0,761 dapat diartikan bahwa 76,1 persen variabilitas konstruk niat membeli kembali dijelaskan oleh variabel pengalaman dan persepsi nilai pelanggan, sedangkan 23,9 persen variabel niat membeli kembali dijelaskan oleh variabel di luar model.

Gambar 2 menunjukkan model struktural, sebagai model reflektif dimana covariance pengukuran indikator dipengaruhi oleh konstruk laten atau mencerminkan variasi dari konstruk unidimensional yang digambarkan dengan bentuk elips dengan beberapa anak panah dari konstruk ke indikator. Model ini 
menghipotesiskan bahwa perubahan pada konstruk laten akan mempengaruhi perubahan pada indicator.

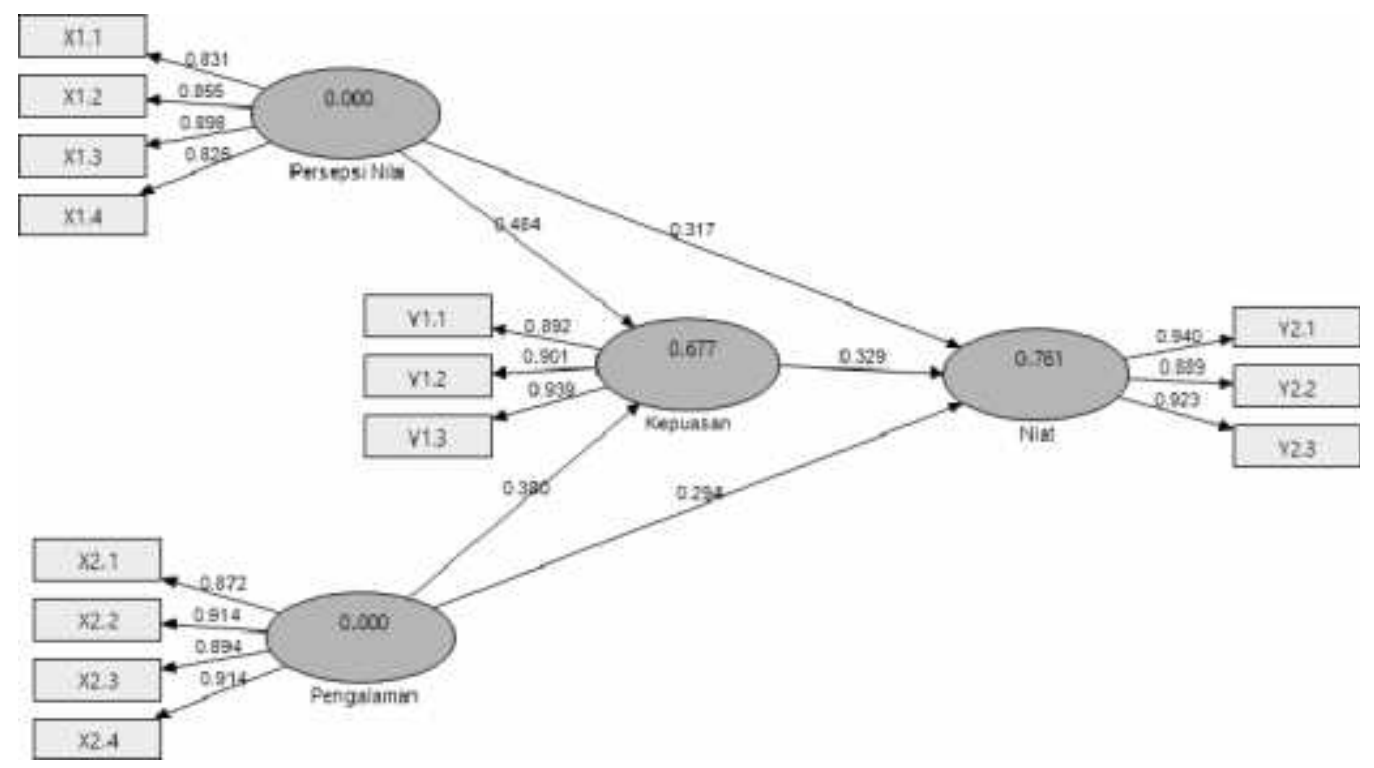

Gambar 2. Diagram Jalur Model Analisis

Sumber: Data primer diolah, 2018

Tabel 8.

Path Coefficient (Mean, STDEV, T-VALUES)

\begin{tabular}{lccccc}
\hline & $\begin{array}{c}\text { Original } \\
\text { Sample } \\
(\mathbf{O})\end{array}$ & $\begin{array}{c}\text { Sample } \\
\text { Mean } \\
(\mathbf{M})\end{array}$ & $\begin{array}{c}\text { Standard } \\
\text { Deviation } \\
(\text { STDEV) }\end{array}$ & $\begin{array}{c}\text { Standard } \\
\text { Error } \\
(\text { STERR) }\end{array}$ & $\begin{array}{c}\text { T Statistics } \\
(\text { (|O/STERR) }\end{array}$ \\
\hline Kepuasan -> Niat & 0,329 & 0,338 & 0,078 & 0,078 & 4,202 \\
Pengalaman -> Kepuasan & 0,380 & 0,377 & 0,071 & 0,071 & 5,378 \\
Pengalaman -> Niat & 0,294 & 0,292 & 0,081 & 0,081 & 3,646 \\
Persepsi Nilai -> Kepuasan & 0,484 & 0,486 & 0,063 & 0,063 & 7,643 \\
Persepsi Nilai -> Niat & 0,317 & 0,310 & 0,072 & 0,072 & 4,402 \\
\hline
\end{tabular}

Sumber: Data primer diolah, 2018

Tabel 7 menunjukkan hasil dari olahan data PLS. Seluruh angka koefisien jalur memiiki angka t-statistik $(|\mathrm{O} / \mathrm{STERR}|)$ diatas 1,96 dengan signifikansi 5 persen, sehingga hasil dari semua hubungan memiliki pengaruh yang signifikan. Seluruh angka original sample $((\mathrm{O}))$ positif, berarti semua hubungan memiliki pengaruh yang positif. 
Tabel 9.

Pengaruh Langsung, Pengaruh Tidak Langsung dan Pengaruh Total Variabel Persepsi Nilai, Pengalaman, Kepuasan Pelanggan, dan Niat Membeli Kembali

\begin{tabular}{clc}
\hline Tipe Pengaruh & \multicolumn{1}{c}{ Konstruk } & $\begin{array}{c}\text { Standardized } \\
\text { Estimates }\end{array}$ \\
\hline & Kepuasan -> Niat Membeli Kembali & 0,329 \\
& Pengalaman -> Kepuasan Pelanggan & 0,380 \\
Pengaruh Langsung & Pengalaman -> Niat Membeli Kembali & 0,419 \\
& Persepsi Nilai -> Kepuasan Pelanggan & 0,484 \\
& Persepsi Nilai -> Niat Membeli Kembali & 0,476 \\
Pengaruh Tidak & Persepsi Nilai -> Kepuasan Pelanggan -> Niat & 0,159 \\
Langsung & Membeli Kembali & 0,125 \\
& Pengalaman -> Kepuasan Pelanggan -> Niat & \\
Pengaruh Total & Membeli Kembali & 0,635 \\
& Persepsi Nilai -> Niat Membeli Kembali & 0,544 \\
\hline
\end{tabular}
Sumber: Data primer diolah, 2018

Berdasarkan perhitungan sobel, pengujian sobel yang pertama menunjukkan koefisien z sebesar 3,6735 (>1,96), dengan signifikansi $0,000<0,05$ menunjukkan bahwa kepuasan pelanggan secara signifikan memediasi pengaruh antara persepsi nilai dan niat membeli kembali. Pengujian sobel yang kedua menunjukkan koefisien z sebesar 3,2777 (>1,96), dengan signifikansi $0,000<0,05$ menunjukkan bahwa kepuasan pelanggan secara signifikan memediasi pengaruh antara pengalaman dan niat membeli kembali.

Hasil Tabel 7 mengindikasikan hipotesis $\mathrm{H}_{1}$ dalam penelitian ini dapat diterima. Hasil ini menjelaskan bahwa semakin baik nilai yang dirasakan oleh pelanggan, semakin meningkatkan kepuasan pelanggan akan produk Toyota Avanza di Kota Denpasar. Hasil ini sejalan dengan penelitian terdahulu yang pernah dilakukan oleh Wibowo dkk. (2014), menjelaskan bahwa persepsi nilai memiliki dampak yang signifikan terhadap kepuasan yang dirasakan oleh pelanggan. Penelitian ini juga didukung oleh beberapa penelitian serupa lainnya, Adhy (2016), mengemukakan bahwa peningkatan pada persepsi nilai berpengaruh 
terhadap peningkatan kepuasan pelanggan. Selain itu menurut Hume \& Mort (2014), persepsi nilai akan mempengarui kepuasan pelanggan yang tercipta melalui kombinasi dari kualitas layanan. Allameh et al. (2013) menyebutkan pula bahwa persepsi nilai berpengaruh secara signifikan terhadap terciptanya kepuasan pelanggan.

Hasil Tabel 7 mengindikasikan hipotesis $\mathrm{H}_{2}$ dalam penelitian ini dapat diterima. Hasil ini menjelaskan bahwa semakin baik pengalaman yang dirasakan pelanggan Toyota Avanza di Kota Denpasar akan meningkatkan kepuasan pelanggan akan produk Toyota Avanza. Hal ini didukung oleh penelitian terdahulu yang dilakukan Sun et al. (2016), menjelaskan bahwa akumulasi dari informasi produk dan pengalaman dalam berbelanja selama transaksi akan mempengaruhi persepsi kualitas dan kepuasan pelanggan. Idris (2017) juga mengemukakan bahwa penglaman pelanggan akan berdampak secara signifikan terhadap kepuasan pelanggan akan suatu produk atau jasa. Penelitian ini juga didukung oleh Suandana dkk. (2016), tingkat kepuasan pelanggan pada produk yang dibeli dipengaruhi oleh kepuasan pelangga terkait produk. Serta menurut Azhari dkk. (2015) yang menyebutkan bahwa pelanggan yang telah mendapatkan pengalaman menarik serta mendapatkan sesuatu yang melebihi harapan pelanggan saat itulah pelanggan mendapatkan kepuasan

Hasil Tabel 7 mengindikasikan hipotesis $\mathrm{H}_{3}$ dalam penelitian ini menyatakan bahwa persepsi nilai berpengaruh positif dan signifikan terhadap niat membeli kembali dapat diterima. Hasil ini menjelaskan bahwa, semakin baik nilai yang dirasakan oleh pelanggan Toyota Avanza di Kota Denpasar, dapat 
Ketut Adi Ananta Shantika, Peran Kepuasan Pelanggan..

meningkatkan niat pelanggan untuk membeli kembali Toyota Avanza. Hal ini disetujui pula oleh penelitian terdahulu yang pernah dilakukan oleh Fang et al. (2016) persepsi nilai menunjukkan predictor yang signifikan dan positif, dengan naiknya persepsi nilai akan meningkatkan niat membeli kembali. Younus et al. (2015) menyatakan bahwa semakin tinggi persepsi nilai akan berdampak positif terhadap tingginya niat konsumen untuk membeli. Pernyataan ini juga didukung oleh Ayuniar dkk. (2017), yang mengemukakan bahwa persepsi nilai berpengaruh terhadap terciptanya niat membeli kembali, serta Ruminten \& Nurhadi (2014) menyebutkan bawha persepsi nilai yang dimiliki tiap pelanggan memiliki peranan penting terhadap minat pembelian ulang. Lei et al. (2014), menyatakan bahwa persepsi nilai memiliki hubungan yang positif dengan niat membeli kembali.

Hasil Tabel 7 mengindikasikan hipotesis $\mathrm{H}_{4}$ dalam penelitian ini menyatakan bahwa pengalaman berpengaruh positif dan signifikan terhadap niat membeli kembali dapat diterima. Hasil ini menjelaskan bahwa semakin baik pengalaman yang dirasakan oleh pelanggan Toyota Avanza di Kota Denpasar, dapat meningkatkan niat pelanggan untuk kembali melakukan pembelian Toyota Avanza di masa yang akan datang. Hal ini sejalan dengan penelitian terdahulu yang pernah dilakukan oleh Idris (2017), bahwa atribut produk, persepsi nilai, pengalaman konsumen, dan kepuasan pelanggan berpengaruh positif dan signifikan terhadap niat membeli kembali suatu produk, hal ini didukung pula oleh Hussein (2018) yang mengemukakan bahwa pengalaman merk diketahui memiliki pengaruh positif pada loyalitas merk, yang dapat ditunjukkan dengan 
munculnya niat untuk membeli kembali pada merk yang sama di kemudian hari. Hal ini juga turut didukung oleh penelitian sebelumnya yaitu penelitian yang dilakukan oleh Suandana dkk. (2016) yang menyebutkan bahwa pengalaman yang baik dalam mencari informasi produk dan kemudahan dalam bertransaksi secara online berpengaruh terhadap niat pelanggan untuk membeli kembali produk yang sama.

Hasil Tabel 7 mengindikasikan hipotesis $\mathrm{H}_{5}$ dalam penelitian ini menyatakan bahwa kepuasan pelanggan berpengaruh positif dan signifikan terhadap niat membeli kembali dapat diterima. Hasil ini menjelaskan bahwa semakin puas pelanggan selama menggunakan Toyota Avanza di Kota Denpasar dapat meningkatkan niat pelanggan untuk membeli kembali Toyota Avanza di masa yang akan datang. Hal ini sejalan dengan penelitian terdahulu yang pernah dilakukan oleh Lim et al. (2018), menyatakan bahwa niat membeli kembali secara positif dipengaruhi oleh kepuasan pelanggan. Suandana dkk. (2016) menyebutkan bahwa kepuasan pelanggan berpengaruh positif dan signifikan terhadap niat membeli kembali. Chamchuntra \& Fongsuwan (2014) juga mengungkapkan tingkat kepuasan pelanggan akan berdampak pada niat untuk membeli kembali sebuah produk di masa yang akan datang. Hasil penelitian ini juga didukung oleh beberapa penelitian terdahulu lainnya, yaitu Olli \& Nurcaya (2016) yang mengemukakan bahwa semakin tinggi kepuasan pelanggan maka akan semakin tinggi pula niat pembelian ulang. Selain itu Pastikarani \& Astuti (2016) mengungkapkan bahwa, kepuasan pelanggan berpengaruh terhadap minat beli ulang. Bindroo et al. (2016) mengungkapkan pula bahwa hubungan antara 
Ketut Adi Ananta Shantika, Peran Kepuasan Pelanggan..

kepuasan dan niat membeli kembali sedikit rumit, dengan faktor yang termanifestasikan pada kesadaran akan ukuran dan harga. Goh et al. (2016) menyebutkan bahwa semakin puas pelanggan, akan menciptakan keinginan pelanggan untuk kembali membeli produk yang sama. Serta penelitian terdahulu yang dilakukan oleh Chun et al. (2014) menyebutkan bahwa ekuitas merek, kepuasan pelanggan dan brand resonance akan secara langsung mempengaruhi niat untuk membeli kembali.

Hasil Uji Sobel pertama menunjukkan bahwa nilai koefisien $\mathrm{z}$ adalah 3,6735> 1.96 dengan tingkat signifikansi $0,000<0,05$, sehingga $\mathrm{H}_{6}$ diterima. Hasil tersebut mengindikasikan bahwa kepuasan pelanggan secara signifikan mampu memediasi pengaruh persepsi nilai terhadap niat membeli kembali. Hasil ini menjelaskan bahwa semakin baik nilai yang dirasakan oleh pelanggan Toyota Avanza di Kota Denpasar terhadap produk, akan meningkatkan niat pelanggan untuk membeli kembali Toyota Avanza di masa yang akan datang. Selain secara langsung, persepsi nilai juga mampu meningkatkan niat membeli kembali melalui kepuasan pelanggan. Hal ini sejalan dengan penelitian terdahulu yang pernah dilakukan oleh Idris (2017) kepuasan pelanggan dapat menjadi variabel mediasi antara persepsi nilai yang dimiliki oleh pelanggan terhadap terciptanya minat untuk membeli kembali. Shih \& Chia (2016) juga mengungkapkan bahwa persepsi nilai pelanggan akan mempengaruhi kepuasan pelanggan, yang akan berdampak pula pada niat membeli kembali. Lam et al. (2016) mengungkapkan bahwa persepsi nilai secara tidak langusng dapat mempengaruhi niat membeli kembali secara positif melalui kepuasan dan kepercayaan. Selain itu Kassim et al. 
(2014) menyebutkan bahwa persepsi nilai secara langsung dapat mempengaruhi kepuasan pelanggan, dengan kepuasan pelanggan dapat mempengaruhi loylitas merk, sehingga dengan terciptanya nilai yang baik di benak pelanggan akan meningkatkan niat pelanggan untuk melakukan pembelian ulang.

Hasil Uji Sobe kedua menunjukkan bahwa nilai koefisien z adalah 3,2777 > 1.96 dengan tingkat signifikansi $0,000<0,05$, sehingga $\mathrm{H}_{7}$ diterima. Hasil tersebut mengindikasikan bahwa kepuasan pelanggan secara signifikan mampu memediasi pengaruh pengalaman terhadap niat membeli kembali. Hasil ini menjelaskan bahwa semakin baik pengalaman yang dirasakan oleh pelanggan Toyota Avanza di Kota Denpasar dapat meningkatkan niat pelanggan untuk membeli kembali Toyota Avanza di masa yang akan datang. Selain secara langsung, persepsi nilai juga mampu meningkatkan niat membeli kembali melalui kepuasan pelanggan. Hal ini sejalan dengan penelitian terdahulu yang pernah dilakukan oleh Chen et al. ( 2015) loyalitas pelanggan dapat secara signifikan dipengaruhi oleh informasi kualitas produk, kualitas produk dan kualitas sistem yang dirasakan oleh pelanggan, serta kepuasan pelanggan. Penelitian ini juga didukung oleh penelitian yang dilakukan oleh Suandana dkk. (2016), menyebutkan bahwa kepuasan pelanggan sangat signifikan dan cukup memediasi pengaruh pengalaman membeli secara online terhadap niat membeli kembali, serta Idris (2017) mengemukakan bahwa variabel independen yaitu atribut produk, persepsi nilai, dan pengalaman pelanggan berpengaruh positif terhadap minat beli ulang melalui kepuasan pelanggan sebagai variabel intervening. 
Ketut Adi Ananta Shantika, Peran Kepuasan Pelanggan..

Berdasarkan hasil dari penelitian ini, dapat disimpulkan bahwa: 1) Persepsi nilai secara positif dan signifikan mempengaruhi kepuasan pelanggan, ini berarti semakin baik nilai yang diperoleh pelanggan, semakin puas pelanggan tersebut. 2) Pengalaman secara positif dan signifikan mempengaruhi kepuasan pelanggan, ini berarti semakin baik pengalaman yang dirasakan pelanggan, akan membuat pelanggan lebih puas. 3) Persepsi nilai secara positif dan signifikan mempengaruhi niat membeli kembali, ini berarti semakin tinggi nilai yang diperoleh pelanggan, semakin tinggi niat pelanggan untuk kembali membeli produk tersebut. 4) Pengalaman secara positif dan signifikan mempengaruhi niat membeli kembali, ini berarti semakin baik pengalaman yang dirasakan, semakin tinggi niat pelanggan untuk melakukan pembelian ulang. 5) Kepuasan pelanggan secara positif dan signifikan mempengaruhi niat membeli kembali, ini berarti semakin puas pelanggan, semakin tinggi niat untuk melakukan pembelian ulang. 6) Kepuasan pelanggan secara signifikan memadiasi pengaruh dari persepi nilai terhadap niat membeli kembali, ini berarti niat pelanggan untuk melakukan pembelian ulang akan meningkat jika persepsi nilai dapat mengingkatkan kepuasan pelanggan. 7) Kepuasan pelanggan secara signifikan memediasi pengaruh pengalaman terhadap niat membeli kembali, ini berarti niat membeli kembali akan meningkat jika pengalaman dapat meningkatkan kepuasan pelanggan.

Berdasarkan hasil penelitian maka penulis memberikan saran yang diharapkan dapat membantu berbagai pihak, yaitu hasil penelitian menunjukkan bahwa kepuasan pelanggan memiliki pengaruh yang paling tinggi jika 
dibandingkan dengan pengaruh persepsi nilai dan pengalaman terhadap terciptanya niat untuk membeli kembali. Maka dari itu bagi produsen Toyota Avanza, diharapkan dapat selalu berupaya untuk meningkatkan kepuasan pelanggan. Terdapat tiga aspek yang perlu ditingkatkan oleh produsen Toyota Avanza untuk meningkatkan niat membeli kembali Toyota Avanza di Kota Denpasar, yaitu menambahkan nilai kemewahan terkait produk, memperbarui desain interior dan eksterior, serta menambahkan fitur produk sehingga meningkatkan nilai manfaat yang bisa diperoleh oleh pelanggan. Bagi peneliti selanjutnya, diharapkan agar dapat melakukan penelitian dengan ruang lingkup yang lebih kompleks, dengan menambah variabel lain diluar penelitian ini, atau bahkan dengan lokasi penelitian yang lebih luas.

Keterbatasan yang ditemukan dalam penelitian ini, yaitu penelitian ini hanya sebatas meneliti mengenai pengaruh persepsi nilai, pengalaman, dan kepuasan pelanggan terhadap niat membeli kembali di Kota Denpasar, dengan hasil penelitian yang tidak dapat digeneralisir maupun tidak dapat digunakan pada daerah lain maupun pada produk lain. Selain itu, penelitian ini hanya sebatas pada pelanggan produk Toyota Avanza yang berada di Kota Denpasar, dalam lingkup yang relatif kecil, dengan pengambilan data secara cross section sehingga dapat menimbulkan hasil yang berbeda jika terdapat penelitian serupa di waktu yang berbeda.

\section{REFERENSI}

Adhy, K. A. (2016). Kepuasan Konsumen sebagai Variabel Mediasi Antara Persepsi Nlai, Persepsi Kualitas dan Citra Merek dengan Loyalitas. Journal \& Proceeding FEB Unsoed, 6(1), 216-236690.

Allameh, S. M., Pool, J. K., Jaberi, A., Salehzadeh, R., \& Asadi, H. (2013). 
Factors influencing sport tourists' revisit intentions: The role and effect of destination image, perceived quality, perceived value and satisfaction. Asia Pacific Journal of Marketing and Logistics, 27(2), 191-207. https://doi.org/10.1108/APJML-12-2013-0159

Ayuniar, D., Rachma, N., \& Slamet, A. R. (2017). Pengaruh Persepi Harga, Persepsi Merek, Terhadap Minat Beli Ulang Dengan Persepsi Nilai Sebagai Variabel Intervening. E-Jurnal Riset Manajemen PRODI MANAJEMEN, 115-129. https://doi.org/10.1123/ijsb.8.1.1

Azhari, M. I., Fanani, D., \& Mawardi, M. K. (2015). Pengaruh Customer Experience Terhadap Kepuasan Pelanggan dan Loyalitas Pelanggan. Jurnal Administrasi Bisnis, 28(1), 1-6.

Bindroo, V., He, X., \& Echambadi, R. (2016). Satisfaction-Repurchase Intentions Relationship: Exploring the Contingent Roles of Consideration Set Size and Price Consciousness. Customer Needs and Solutions, 3, 115-125. https://doi.org/10.1007/s40547-016-0067-2

Chamchuntra, S., \& Fongsuwan, W. (2014). Customer Repurchase Intention , Trust and Customer Satisfaction Influecing Outsourced Employees At Kasikornbank Bank Public Company Limited ( Thailand ). International Journal of Arts \& Sciences, 07(03), 233-242.

Chen, J. V., Yen, D. C., Pornpriphet, W., \& Widjaja, A. E. (2015). E-commerce web site loyalty: A cross cultural comparison. Information Systems Frontiers, 17(6), 1283-1299. https://doi.org/10.1007/s10796-014-9499-0

Chun, C. H., Szu, W. Y., Cheng, Y. L., \& Te, P. C. (2014). the Relationship Among Brand Equity, Customer Satisfaction, and Brand Resonance To Repurchase Intention of Cultural and Creative Industries in Taiwan. The International Journal of Organization Innovation, 6(3), 106-121. https://doi.org/10.1109/4.962282

Fang, J., Wen, C., George, B., \& Prybutok, V. R. (2016). Consumer Heterogeneity, Perceived Value, and Repurchase Decision-Making in Online Shopping: the Role of Gender, Age , and. Journal of Electronic Commerce Research, 17(2), 116-131.

Gaikindo. (2018). Adu Balap Penjualan Mobil Avanza dengan Xpander. Retrieved from https://databoks.katadata.co.id/datapublish/2018/05/28/adubalap-penjualan-mobil-avanza-dengan-xpander

Goh, S. K., Jiang, N., \& Tee, P. L. (2016). The Impact of Brand trust, Self-image 
Congruence and Usage Satisfaction toward Smartphone Repurchase Intention. International Review of Management and Marketing, 6(3), 436441. Retrieved from http:\%0Awww.econjournals.com

Harsono, R. (2016). the Impact of Marketing Mix ( 4P' S ) on Customer Loyalty Towards Toyota Avanza. IBuss Management, 4(1), 1-7.

Hume, M., \& Mort, G. S. (2014). The consequence of appraisal emotion, service quality, perceived value and customer satisfaction on repurchase intent in the performing arts. Journal of Services Marketing, 24(2), 170-182. https://doi.org/10.1108/08876041011031136

Hussein, A. S. (2018). Effects of Brand Experience on Brand Loyalty in Indonesian Casual Dining Restaurant: Roles of Customer Satisfaction and Brand of Origin. Tourism and Hospitality Management, 24(1), 119-132. https://doi.org/10.20867/thm.24.1.4

Idris, A. D. M. (2017). Pengaruh Faktor Atribut Produk, Persepsi Nilai, dan Pengalaman Konsumen Terhadap Minat Bli Ulang yang Dimediasi oleh Kepuasan Konsumen. Diponegoro Journal Of Management, 6(4), 1-9. Retrieved from http://ejournal-s1.undip.ac.id/index.php/dbr

Kassim, A. W. M., Igau, O. A., Harun, A., \& Tahajuddin, S. (2014). Mediating Effect of Customer Satisfaction on Perceived Product Quality, Perceived Value, and Their Relation to Brand Loyalty. International Journal of Research in Management \& Business Studies, 1(2), 13-18.

Kusniarti, A. S. (2018). Avanza Masih Dominasi di Bali Meski BPS Catat Penjualan Mobil Triwulan II-2018 Mengalami Penurunan. Retrieved from http://bali.tribunnews.com/2018/08/31/avanza-masih- dominasi-di-balimeski- bps-catat-penjualan-mobil-triwulan-ii-2018-mengalami-penurunan? page $=2$

Lam, A. Y. C., Lau, M. M., \& Cheung, R. (2016). Modelling the Relationship among Green Perceived Value, Green Trust, Satisfaction, and Repurchase Intention of Green Products. Contemporary Management Research, 12(1), 47-60. https://doi.org/10.7903/cmr.13842

Lei, Y. W., Kuan, Y. C., Po, Y. C., \& Shu, L. C. (2014). Perceived Value, Transaction Cost, and Repurchase-Intention in Online Shopping: A Relational Exchange Perspective. Journal of Business Research, 67(1), 2768-2776. https://doi.org/10.1016/j.jbusres.2012.09.007

Lim, X. J., Aw, E. C., \& Teoh, K. G. (2018). Factors Influencing Repurchase Intention in Online Shopping Context: the Mediating Role of Satisfaction. Journal of Applied Structural Equation Modelling, 2(1), 29-43. 
Olli, K. R. R., \& Nurcaya, I. N. (2016). Peran Kepuasan Pelanggan dalam Memediasi Pengaruh Experiental Marketing terhadap Pembelian Ulang Tiket Pesawat pada PT Jasa Nusa Wisata Denpasar. E-Jurnal Manajemen Unud, 5(8), 4835-4864.

Oto.com. (2018). Toyota Avanza. Retrieved from www.oto.com/mobilbaru/toyota/avanza

Pappas, I. O., Pateli, A. G., Giannakos, M. N., \& Chrissikopoulos, V. (2014). Moderating Effects of Online Shopping Experience on Customer Satisfaction and Repurchase Intentions. International Journal of Retail and Distribution Management, 42(3), 187-204. https://doi.org/10.1108/IJRDM-03-2012-0034

Pastikarani, D. A., \& Astuti, S. R. T. (2016). Analisis Pengaruh Faktor-Faktor Minat Beli Ulang dengan Kepuasan Pelanggan Sebagai Variabel Intervening. Diponegoro Journal Of Management, 5(2), 1-9.

Putra, I. K. S. W., Setiawan, P. Y., \& Respati, N. N. R. (2018). Pengaruh Persepi Negara Asal terhadap Niat Beli Ulang Dimediasi oleh Ekuitas Merek. EJurnal Manajemen Unud, 7(7), 3974-4001.

Rahyuda, K. (2016). Metode Penelitian Bisnis. (Jiwa Atmaja, Ed.). Denpasar: Udayana Press.

Ruminten, M., \& Nurhadi. (2014). Pengaruh Persepsi Nilai , Kualitas Pelayanan , dan Kepuasan Pelanggan terhadap Minat Pembelian Ulang Jasa Ekspedisi. Jurnal Hasil Riset, 1-7. Retrieved from https://www.dropbox.com/s/gsto4g1oeo8ihiq/jpmanajemendd140489.pdf?dl $=0$

Shih, W. C., \& Chia, S. H. (2016). Understanding online repurchase intention: social exchange theory and shopping habit. Information Systems and EBusiness Management, 14(1), 19-45. https://doi.org/10.1007/s10257-0150272-9

Suandana, N. P. W., Rahyuda, K., \& Yasa, N. N. K. (2016). Pengaruh Pengalaman Membeli Produk Fashion Terhadap Niat Membeli Kembali Melalui Kepuasan dan Kepercayaan Pelanggan. Jurnal Manajemen, Strategi Bisnis Dan Kewirausahaan, 10(1), 85-97.

Sun, H., Ni, W., \& Wang, Z. (2016). A Consumption System Model Integrating Quality, Satisfaction and Behavioral Intentions in Online Shopping. Information Technology and Management, 17(2), 165-177. 
E-Jurnal Manajemen, Vol. 8, No. 6, $2019: 3902-3929$

https://doi.org/10.1007/s10799-015-0254-0

Wibowo, S. F., Sarih, I. P., \& Kresnamurti, A. (2014). Pengaruh Persesi Kualitas Pelayanan dan Persepsi Nilai terhadap Kepuasan Pelanggan. Jurnal Riset Manajemen Sains Indonesia, 5(2), 304-324. https://doi.org/10.1007/s00198013-2493-4

Younus, S., Rasheed, F., \& Zia, A. (2015). Identifying the Factors Affecting Customer Purchase Intention. Global Journal of Management and Business Research, 15(2), 8-14. https://doi.org/10.14738/assrj.21.139. 